\title{
1. Land and Life in Timor-Leste: Introduction
}

\author{
Andrew McWilliam and Elizabeth G. Traube
}

\section{Post Occupation}

In the aftermath of the Indonesian occupation (1975-99) and the bittersweet triumph of the resistance struggle, Timor-Leste emerged as the first new nation of the twenty-first century. ${ }^{1}$ The path to independence, however, was a rocky one and left a deep legacy of suffering and social dislocation. In the chaotic withdrawal of Indonesian forces, a final bout of violence, property destruction and population displacement left the half-island nation a smoking ruin under the protection of a multinational peacekeeping force: the International Force for East Timor (Interfet).

Ten years on, the process of rebuilding continues. A constitutional democratic system of parliamentary government has been established, oil and gas revenues now provide sustainable funds for much needed infrastructure, and government services are gradually being reinstated to support economic livelihoods for a growing population. Social life in the villages and scattered settlements is once again focused on the seasonal rhythm of agriculture and the rituals of exchange that mark life-cycle ceremonies and the conduct of rural sociality. Still, the path to a peaceful prosperity has not been without setbacks - most dramatically exemplified in the round of inter-communal violence and property destruction that erupted in the capital, Dili, during 2006. The intense period of civil disorder was fuelled by a powerful mix of ethnicised political and economic rivalries, corrosive youth unemployment and tensions over housing. If independence was built on the unity of struggle and shared suffering, the post-independence landscape is a more fragmented mosaic of crosscutting positions, competing claims and aspirations.

In the wake of these events and the opportunities afforded an open political environment for the first time in a generation, Timor-Leste has attracted the attention of a new wave of social-science researchers. Most are drawn to the island with a shared interest in exploring and documenting the aftermath of occupation and the diverse challenges of renewed nation building. The result is a growing body of anthropological research and analysis that charts the shifting

1 The Democratic Republic of Timor-Leste (RDTL) was officially declared (restored) on 20 May 2002. 
fortunes of Timor-Leste society through the micro-politics of local communities adapting to changing circumstances (see Gunn 2007 for a preliminary review). In bringing together a selection of this work, the present volume marks the enthusiastic resumption of comparative ethnographic research in Timor-Leste following a long hiatus, or 'ethnographic gap' as Gunn describes it, when social research under Indonesian rule was actively discouraged.

The present volume is designed as a comparative appreciation of contemporary post-independence social life in Timor-Leste. It brings together a group of anthropologists and established researchers from Europe, the United States and Australia who have been pursuing extended ethnographic research among the diverse language communities of the island. Each of the contributing papers provides a unique perspective on situated processes of social renewal, emphasising the multiple ways that Timorese people are rebuilding connections with one another and their emplaced communities of origin and entitlement.

Central to these efforts of social renewal are the enduring associations that people assert and sustain with the land of their ancestors and the life-giving resources on which all families depend. These connections provide a common theme throughout the papers of the volume and one that underlines the longterm impact of internal displacement and resettlement policies that were widely practised under Indonesian military rule and previous Portuguese colonial governments. Independence has, for the first time in decades, provided opportunities for settlement choice and the possibility of return. At the same time, across Timor-Leste, people have heightened expectations of receiving public goods and services from the new nation-state. Thus, the theme of land and life also brings into view a series of salient framing questions as points of comparative analysis across Timor-Leste society. We interrogate, for instance, the complex ways that Timorese households are making and remaking their ties to land, whether in terms of mythically constituted places of ancestral origin, or to resettlement lands of more recent familiarity where investments in housing and construction preclude easy return to former village lands even if new land security remains uncertain. More generally, we ask what is the status of emplaced tradition and social authority for the majority of the rural population? To what extent do ritually maintained social alliances still guide the production of localities, inscribing connection and informing entitlement? How are different relationships to land implicated in nationalist discourse and the often-contested claims that coalesce around contributions to the national struggle for independence? These and related ideas of social connection and the production of emplaced relationships inform the contributing papers of the collection, providing comparative insights into the everyday worlds of diverse Timorese communities. 


\section{The Flow of Life in Timor-Leste}

In exploring the theme of land and life in Timor-Leste, we seek to make explicit comparative association with the now classic volume edited by James J. Fox (1980) entitled The Flow of Life: Essays on eastern Indonesia. The book marked a significant shift in the direction of ethnographic research on eastern Indonesian societies, moving from a concern with prescriptive organisational structures of the kind developed under Dutch structural anthropology (Josselin de Jong 1977; van Wouden 1968) to an emphasis on more dynamic, shared categories of social reproduction expressed as 'metaphors for living' and typically encoded in pervasive dyadic forms. In his introduction to the volume, Fox noted that the contributing essays converged on a number of crucial social categories, many of them recognisably cognate and forming part of a much broader and shared Austronesian-language cultural heritage. This heritage included ideas around the traditional house and its architectural expressions of social and cosmic principles of order, the role of exchange and social alliance in the reproduction of community, and the general significance of symbolic classification and of certain prominent binary cultural categories expressed in social dynamics. ${ }^{2}$

Six of the 16 papers in The Flow of Life dealt with indigenous language communities of Timor - for the most part based on ethnographic research undertaken during the 1960s and early 1970s. This geographical emphasis reflected an increased anthropological attention accorded Timorese ethnography during the period, particularly among French and US-based researchers. Their work was informed by the prevailing style of structuralist theory, which encouraged a comparative appreciation of the common cultural heritage across the island and the complex patterns of alliance and classification that sustained the 'flow of life' among these communities. The contributors to that collection of papers included many of the prominent ethnographers of Timor at the time: Brigitte Clamagirand writing on the Marobo Kemak people of highland Bobonaro; Elizabeth Traube working with Mambai speakers in Aileu; Shephard Forman on Makassae social orders in highland Baucau; Claudine Friedberg on Bunak cultural practices in central Timor; ${ }^{3}$ Gerard Francillon among Tetun speakers of Wehali (central West Timor); and the Dutch anthropologist Schulte Nordholt revisiting his earlier work among Atoni (Meto) speaking communities of West Timor, which encompassed the region of Oecussi-historically part of East Timor. ${ }^{4}$ Taken

2 Elaborating upon what Needham (1978:12-13) once described as 'primary factors' in a society's symbolic classification and which Fox (1989:45) later expressed as 'symbolic operators'.

3 Friedberg collaborated with her husband, Louis Berthe, on Lamaknen Bunak ethno-botanical research in the border region between East and West Timor.

4 Notable omissions from the list of contributors to The Flow of Life, however, included Maria LameirasCampagnolo (1975), who pursued pioneering doctoral research among Fataluku speakers in Lautem district; David Hicks (1976), who completed research in Viqueque during the 1960s; and Clark Cunningham, who undertook long-term ethnographic work in West Timor about the same time. The legacy of other active 
together, their contributions provided a sustained appreciation of social practices clustered around the mesh of cultural ideas and forms that connected each of the indigenous language communities of Timor into what has become a recognisably shared Austronesian cultural heritage.

It is also notable that The Flow of Life reported on a period of relative political stability in Timor. Despite increasing connections to the outside world, local communities in the still comparatively remote hinterlands and highlands had not been radically transformed by intrusions of modern politico-economic forces and communication technologies. To a significant degree, the depiction of rural Timorese society presented by The Flow of Life remained organised around predominantly ancestral principles and protocols, where the influence of the colonial state had a significant but limited impact on practices of social reproduction.

Much has changed in the interim, with 30 years of dynamic political history and economic change, and an aborted decolonisation process followed by a foreign invasion and sustained military occupation with its accompanying repressive simplifications. There have also been large investments in government services such as roads, communications, health and education, as well as the formation, persistence and eventual victory of a grassroots resistance movement. These factors have all contributed to a substantially altered cultural landscape and the kind of questions that might be asked of the contemporary ethnographic context.

The contributors to this contemporary companion volume to The Flow of Life offer a comparative appreciation of these earlier studies, but they also expand its ethnographic reach both in terms of incorporating new ethno-linguistic regions of Timor into the ethnographic record and in ways that extend and revisit some of the ideas and patterns of practice highlighted in the earlier work. The fact that among the contributors is one of the anthropologists whose research bridges the 'ethnographic gap' between pre and post- Indonesian occupation of Timor-Leste underlines the comparative relevance of the earlier work. Elizabeth Traube has re-engaged her research in Timor-Leste after many years of electing not to pursue field access. She is therefore uniquely placed to reflect on both continuities and transformations in customary communities over this period.

At the conclusion of his introduction to The Flow of Life (1980), Fox noted that the volume marked a new development in the comparative analysis of Austronesian societies. But he cautioned that while the forms of comparison in the papers had concentrated on a few prominent shared social categories, there

Portuguese anthropologists during the period, such as Antonio de Almeida and Ruy Cinatti, while not addressed here, represented the contemporary expression of a longstanding Lusophone research engagement with Timorese society - one that continues in sometimes convergent ways to the present. 
was also a material basis to the societies under study, a basis on which other forms of productive comparison might be made (Fox 1980:18). This observation provides another point of departure for the present collection of papers, which, each in their different ways, integrate perspectives on the material conditions of social life in the sovereign Republic of Timor-Leste. More specifically, they address the different ways that Timorese people assert attachments and claims to place and landscapes of memory and belonging in the contemporary world.

In the process, the papers also engage the legacy of an expanded field of comparative analysis and understanding that developed out of the intellectual lead of The Flow of Life, but which was never specifically applied to questions of ethnography in the politically closed world of Indonesian-occupied Timor. The rapid expansion of ethnographic research from an appreciation of comparative Austronesian cultural ideas and meanings both in eastern Indonesia from the 1980s and in the pan-Pacific field of Austronesian-speaking societies highlighted the remarkable extent of a shared cultural heritage of common language origins. Ideas about the production of place, of topogeny, ${ }^{5}$ precedence, stranger kings and the discourse of origins ramified across the expanded field of comparative Austronesian studies and found diverse application in areas such as prehistoric interpretations (see Bellwood 1996) as well as contemporary articulations of the cultural field (for example, Barraud and Platenkamp 1989; Fox 1989, 1993, 1995, 1997; Fox and Sather 1996; Vischer 2009). As Reuter has noted in a recent comparative collection of Austronesian-based ethnography that focuses on material and emplaced conditions of social life, 'territorial and social categories are often closely interlinked. Founders and newcomers are afforded a place in Austronesian cosmological models, and their harmonious interaction is no less integral to society than male and female is to the perpetuation of life itself' (2006:35). In the long-deferred return to ethnography in Timor-Leste, the contributors to this volume use these fundamental Austronesian ideas of place and place making, land and social connection as a critical lens through which to observe and investigate contemporary Timorese society and to explore their continuing relevance within a vibrant and politically transformed cultural landscape.

\section{Portuguese Colonial Intervention}

The complex mix of peoples on Timor is the product of multiple histories of migration and expansion into new territories. Archaeological, linguistic and cultural evidence suggests that the earliest inhabitants of the island were Papuan-

5 Topogeny is defined by Fox $(1997: 8,91)$ as 'the recitation of an ordered series of place names', which is analogous with the recitation of a genealogy that indicates precedence in relation to an origin or starting point. 
language speakers. Today Papuan-language speakers are located in central Timor (Bunaq) and in the eastern reaches of the island (including Fataluku, Makassai and Makalero speakers). These groups have interacted with, borrowed from and displaced as well as been displaced by Austronesian newcomers (see Schapper, this volume). Austronesian-speaking peoples first arrived in the region some 3000 years ago. From these, and probably subsequent, migrations of Austronesian speakers derive the majority of the languages now spoken on Timor (Fox 2000:3).

While the Austronesian immigrants came as settlers, other outsiders came to Timor for commercial purposes. By the fourteenth century, the island was already famous for its sandalwood and was visited regularly by Chinese and Javanese traders. The sandalwood trade also attracted Europeans. The Portuguese were the first to arrive and would be the last to leave. During the sixteenth century, Portuguese traders and missionaries established bases on the islands of Solor, Flores and Timor. Unions between the traders and native women gave rise to a Portuguese-speaking mestizo population, variously known as Topasses or Larantukans, who became the dominant force in the sandalwood trade. While the Dutch established themselves in Kupang, on the western tip of Timor, the Portuguese attempted, with little success, to assert control over the Topasses from Goa. In 1701, the first governor appointed by the Portuguese Crown took up residence in Lifao, originally a Topass-controlled settlement, on the northwestern coast of Timor. But the Portuguese position remained precarious, as successive colonial governments faced opposition from the Dutch, the Topasses and indigenous groups. In 1769, besieged by the Topasses, the Portuguese Governor, Antonio José Telles de Menezes, abandoned Lifao and fled eastward to Dili.

From their new base in Dili, the Portuguese established fortresses along the northern coast and began looking eastward and southward, into the interior. But while the transfer of the capital brought some measure of security from Dutch and Topass attacks, the handful of Portuguese in Dili remained dependent on fragile alliances with local chiefs. ${ }^{6}$ Until well into the twentieth century colonial rule was largely 'indirect', with the Portuguese endeavouring to insert themselves into local tributary arrangements. This required identifying local political authorities - a project that proved challenging for the colonisers and consequential for the local systems. Both the Dutch and the Portuguese had perceived western Timor as divided into the two 'empires' of Sonba'i and Belu (or Servião and Bello in Portuguese orthography). Leaving the accuracy of that characterisation aside, the situation was still more fluid in the east, where dozens of small local political communities were materialised through

6 Indeed, missionisation efforts were set back by the transfer, as they had to be begun again, with the peoples surrounding Dili (Durand 2004:57). 
ritual performances and tributary arrangements. These communities were conceptualised as hierarchical orderings of named ancestral origin houses, which played determinate roles in annual seasonal rituals, the collection of harvest tribute and warfare. Leadership was dyadically distributed between symbolically immobile sacral authorities, oriented to the cosmic powers of the inside, and active executives oriented to the outside, responsible for regulating human affairs and protecting the boundaries of the realm. Not surprisingly, the Portuguese dealt primarily with the latter, who better fit European conceptions of rule. They contracted alliances with local leaders by distributing military patents, ranked from colonel to lieutenant, and insignia of rule, such as staffs, flags and military drums. The recipients pledged loyalty to the Crown and agreed to send tribute in kind (amassed from their 'subjects') to the Portuguese in Dili and to raise troops to assist them in punitive expeditions against 'rebellious' rulers. The Portuguese referred to such executive figures as 'kings' (rei) or 'rulers' (regulo) and to the territories perceived to be under their jurisdiction as 'kingdoms' or reino; the last term entered into and remains common in indigenous vernaculars. The term rei was later partially replaced with the Tetun title liurai - literally, 'he who crosses over the land'.

For Timorese executive leaders, both the military titles and the relationship to the outsiders they signified were a valuable political currency, while the obligation to help suppress rebellions could be used pragmatically in putting down one's own rivals. For the Portuguese, however, the system of tributary alliances became increasingly inefficient and unreliable. Today's loyal ally might be tomorrow's rebel, and no matter how many punitive expeditions they mounted, another revolt always ensued, leaving a legacy of periodic havoc with violent blood-letting including headhunting, the destruction of settlements and the enslavement of war captives (see Pélissier 1996). During the latter half of the nineteenth century, as Lisbon and The Hague negotiated a treaty that would formally assign to the Portuguese the eastern half of the island, as well as the enclave of Oecusse, the actual Portuguese ability to control this territory remained tenuous at best (Fox 2000:16).

Beginning in the late nineteenth century, however, the Portuguese implemented a series of initiatives designed to solidify, extend and rationalise colonial control. Administrative reforms linked Timor more tightly with Goa and Macau, and, after 1896, to Portugal as a direct colonial dependency. The introduction of coffee cultivation by Governor Affonso de Castro (1859-63) anticipated a shift away from the tributary economy and the development of an export plantation economy, which would require the 'pacification' of the interior (Gunn 2001:8-9). At the turn of the century, Governor José Celestinho da Silva (1894-1908) initiated a military campaign aimed at ending the chronic rebellions and transforming Timor into a properly civilised, Europeanised colony (Pélissier 1996:190); the 
military task was inherited and completed by his successor, Filomeno de Câmara. The two governors faced a common adversary in the 'kingdom' of Manufahi, where two successive rulers, Dom Duarte and his son, Dom Boaventura, resisted the tightening of colonial controls. Among Boaventura's grievances was the replacement in 1909 of tribute in kind with a cash-based head tax-a key element in colonial visions of socioeconomic development. Resentment of the head tax was widespread and resistance to it would prove long lived. Nevertheless, the defeat of the second Manufahi Revolt of 1911-12 marked a transition in Timorese-Portuguese political relations. If the rebellion had given expression to a deeply rooted anti-colonial sentiment - a persistent desire to expel the Europeans from the land - the Timorese collaborators mobilised in the campaign to suppress it became witnesses to the heightened level of military technology available and the extreme brutality directed against the defeated. ${ }^{7}$ Between 15000 and 25000 people are estimated to have died in the 1911-12 campaigns - approximately 5 per cent of the population at the time (Durand 2009:73). The Manufahi Revolt thus taught Timorese that the potential costs of rebellion had risen sharply.

For the Portuguese, the rebellious Manufaistas confirmed their mistrust of the indigenous leadership. Over the next decades, the colonial government intervened more intensively in Timorese political affairs, replacing many traditional ruling families with their own appointees (Pélissier 1996:297-8). Intensified efforts to educate the sons of rulers created a small Europeanised, Catholic, Portuguese-speaking elite, who were recruited into an expanding colonial bureaucracy. Following the military pacification of the colony, the Portuguese imposed a uniform system of administration across the territory. The colony was divided into 10 administrative districts (conçelhos), each of which was divided into subdistricts (postos). In most subdistricts, the old 'kingdoms' were preserved as the next level of organisation, but they were conceived as purely administrative units, the leaders of which would receive and relay directives from the district and subdistrict administrators. Ignoring the local hierarchies of origin villages, the Portuguese treated these 'kingdoms' as fixed territories composed of residential villages, which were designated by the Tetun term suku (in Portuguese, suco) and further subdivided into hamlets (aldéia). The district and subdistrict heads were appointed from Dili and were typically European or mestizo; they in turn appointed the village and hamlet heads; the former, the chefe de suco, came to be addressed as liurai, though few of them came from traditional ruling lines.

While the administrative system was designed to fix individuals to specific territories, at least for purposes of taxation, the twentieth century also saw

7 Gunn (2001:7) observes that the implementation of the steam gunboat was crucial to Portugal's defeat of the Manufaistas. 
a number of involuntary displacements of populations. The most dramatic took place during World War II, when the Japanese invaded and occupied Portuguese Timor (1941-45); some 60000 Timorese are estimated to have died during the occupation, in reprisals for Timorese support given to Australian commandos, as well as in renewed intra-Timorese hostilities incited by the Japanese occupiers. After the war, when West Timor became part of the new Republic of Indonesia, Portugal, with Allied support, resumed colonial control of its easternmost province. The postwar decades of Portuguese colonial rule on Timor were characterised by mounting political repression (enforced through Prime Minister Salazar's secret police, the Polícia Internacional de Defesa do Estado or PIDE) and somewhat erratic projects of economic development, such as the Government's efforts in the 1960s to induce a shift of population to the southeast coast - a terrain seen as hospitable to intensive rice cultivation (Fox 2000:24).

In 1974 the abrupt overthrow of the Estado Novo in Portugal made decolonisation an imminent necessity. Without discounting its violence, Portuguese colonial rule would be taken to task more for neglect than for direct exploitation of the subject population. As a non-settler colonial power, the Portuguese had depended historically on mobilising some Timorese against others (Robinson 2001:283), and even the major twentieth-century 'pacification' campaigns were waged with indigenous support. The idea of transforming the Timorese into industrious, productive, civilised modern subjects was a persistent theme in Portuguese colonial ideology, but efforts at its realisation were lacklustre, while neither the massive relocation nor the extermination of the population was ever part of the Portuguese colonial vision. In a terrible irony, the people of Timor-Leste would experience the 24-year Indonesian occupation of their land as a greater threat to their existence than had 400 years of disparate Portuguese colonial rule.

\section{Mobility, Origins, Displacement and Return}

One of the enduring legacies of Indonesian occupation is the degree to which local Timorese populations were displaced and resettled as part of a sustained policy to reorganise Timorese society and promote compliant allegiance to Indonesian rule, what Philpott describes as the 'state articulated goals of prosperity' (2000:173). The actual extent of displacement and resettlement is not documented in detail, but it clearly affected the whole population at different times and in varying degrees. ${ }^{8}$ Its impact and consequences continue to inform social and political agendas in contemporary Timor-Leste.

8 Chega! (CAVR 2005) provides a litany of emotional testimonies to the impact of these events across the country. In the absence of official documentation, more precise records of the impact of displacement and forced resettlement across Timor- Leste during the Indonesian occupation would require detailed field research to at least the level of each subdistrict to determine which hamlets (aldeia) were moved, where they were resettled and to what extent there has been a return to former settlement areas. 
The early years following the military invasion were the most keenly felt in this respect. Fitzpatrick (2002:135), for example, cites Indonesian military statistics from 1978, reporting that 372921 people were relocated into more easily controllable areas. Up to 150 camps, known as 'settlement areas' (daerah pemukiman), were established across the territory, with an average camp population of 2000 people. Budiardjo and Liem (1984:81) cite the example of Baucau, where, of the estimated 74000 resident population of the largely rural district at the time, 61000 people were forced to live in cramped conditions around the town of Baucau proper. A report of the situation noted that 'villages (povoção) as we knew them before the Indonesian invasion simply don't exist any more. All village life has stopped. Everyone has been brought together in the settlements around the postos [subdistrict centres]' (TAPOL report cited in Budiardjo and Liem 1984:76). Widespread food shortages and malnutrition were also common at the time and contributed substantially to a high number of reported deaths.

These excesses moderated over time as the territory was gradually brought under general Indonesian military control, but restrictive policies on settlement locations, population movements and cultural practices remained a constraining feature on social life for decades. Settlement relocation policies, particularly to roadsides and the edges of townships, facilitated surveillance and control of the population while permitting economies of scale in the provision of services. These strategies were consciously deployed in an effort to undermine political resistance by weakening perceived allegiances to oppositional cultural networks and authority. Ultimately, however, both coercive and persuasive techniques of rule failed to control the subject population, who, from 1983 on, expressed their disaffection via an increasingly effective clandestine resistance movement.

While these recent experiences of coercive displacement loom large in the dynamics of contemporary Timorese social contexts, they are not without precedent in the historical experiences of Timorese peoples. As we have noted, during the Portuguese colonial period, repeated expeditions to punish rebellious rulers, as well as a succession of militarised occupations in the form of the early twentieth-century Portuguese pacification campaigns, Japanese wartime occupation and the subsequent return of the Portuguese, have all contributed to periods of population upheaval and resettlement.

Although displacement took new and intensified forms under successive foreign occupations, it is not irreconcilable with traditional models of social life. On Timor, as throughout the Austronesian world, mobility is culturally constructed as an inevitable feature of social existence and is interwoven with ideas about origins. Ancestral narratives preserved in Timorese societies recount a potentially endless process of human migration and dispersal, as ancestors set out from named origin places to open up and settle new lands. Such stories 
of mobility revolve around separations and encounters. On the one hand, male ancestors divide their origin houses when they leave them and found new houses that stand to the source house as younger to elder sibling or, in a pervasive botanic idiom, as branch/tip to trunk. Such male-ordered ties between houses are ideally commemorated in rites that reverse the outward movements and reunite scattered house members at acknowledged origin sites. On the other hand, migration stories also describe encounters between earlier settlers and newcomers. These stories, which might be told from both perspectives, commonly conclude with the parties establishing a marital alliance in which immigrant men marry daughters of the original/earlier inhabitants and obtain rights in land in return for their labour and political support as co-residents.

To this extent, Timorese society is predicated on mobility and a cultural preparedness to relocate residence and adjust group relationships in the face of changing circumstances, while preserving connections to ancestral origin places left behind. Reuter (2006:14) describes the interplay of displacement and emplacement as central to defining identity and status in the Austronesian world, arguing that 'no matter how much displacement they might experience, their relationships with the land, their place of origin and their place of residence are matters of utmost importance to all people, and no less so to a people on the move'. In this context, the important consideration is less the nature of involuntary displacement, and rather more the particular conditions under which in-migrants and host communities reach (or fail to reach) negotiated agreements for shared arrangements.

Ironically, the massive displacement precipitated by the Indonesian invasion might have reinforced the cultural value of origin places. In 1975, many administratively created districts and subdistricts 'emptied out', people say, as civilians fled from the invaders behind Falintil. ${ }^{9}$ While people conventionally speak of spending the years of exile in 'the forest' (Tetun: ai laran), they alternated between wild and settled spaces and called on their respective spirit guardians, the spirits of the outside associated with mountains and forest groves, and those of the inside who look after ancestral origin villages, where many people took refuge from the invading Indonesian forces. Moreover, after 1978, when Fretilin ordered the 'surrender' of civilians and turned its armed wing, Falintil, into a guerrilla force, resistance fighters continued to solicit help from the 'hidden world,' by way of its recognised human representatives; as we discuss later, many people regard the ultimate victory of the resistance as at least in part made possible by an alliance between the human and non-human realms. In short, under extraordinary political circumstances, many people might have come to feel an intensified connection to the sacred powers of the land and their human guardians.

9 Forças Armadas de Libertação Nacional de Timor Leste. 
Ritual life was disrupted but not completely suspended during the occupation. While regular physical returns to ancestral origin villages were rendered difficult or impossible, the historical culture of mobility provided considerable flexibility. Indeed, the importance attributed to origin places encourages symbolic strategies for adapting to displacement. Thus, even under conditions of relative stability, any presently occupied sacred place is always understood as a lesser replica of one that is absent, a token of an encompassing type, and there are ritual techniques for linking the space of performances to other, hierarchically superior sacred spaces. For instance, symbolic contiguities might be asserted between a 'branch house' and its 'trunk house', which might be linked in turn, through oratorical and/or sacrificial practices, to a sacred mountain. During the occupation, conventional principles of substitution were enlisted to adapt to Indonesian policies that limited the scale of performances or precluded physical returns to origin places; Susana Barnes, for instance, notes that Nauete-speakers in Viqueque continued to stage 'simplified' harvest rituals and constructed makeshift storehouses for ancestral sacra. Through such means, people preserved the communication with their ancestors through which the unity of scattered house-groups is articulated.

Themes of origins, mobility, displacement and return resonate through the papers. Andrea Molnar's study of Atsabe Kemak communities in the uplands of Ermera accords analytical weight to the place of origins and mythical centres. Here the shifting histories of colonial politics, migration and dislocation have radically complicated social relations, but ideas of 'origin' and the various rhetorical strategies deployed to assert emplaced authority and relative status remain important narrative orientations for constituting and reconstituting the notion of community. Her chapter is explicitly comparative with Clamagirand's earlier ethnography of the mountain Kemak of Marobo (Renard-Clamagirand 1982), revealing in the process the contested nature of origin discourses and the shifting contours of political positioning that accompany all narrative histories.

Origins and mobility are also exemplified in Antoinette Schapper's linguistically inflected contribution exploring the historical expansion of Bunaq-language communities from their origins in the central highlands of Timor. The cultural landscapes of Bunaq, a non-Austronesian language, nevertheless illustrate their long-term engagement with proximate Austronesian speakers. Schapper highlights the complex historical processes of assimilation and adaptation that have accompanied expanding Bunaq settlement strategies in response to shifting political pressures and inducements.

Under Indonesian occupation, local authority structures organised on the basis of appeals to mythical origins held little sway in terms of land management and jurisdictional claims. Customary claims tended to be subsumed or marginalised by successive Indonesian Government regimes privileging their own political 
and developmentalist agendas. In post-occupation Timor-Leste, these older patterns of authority and mythical legitimacy are once again finding traction in the public domain. These ideas are well expressed in Lisa Palmer's contribution to the volume, which focuses not so much on land management as on water sources and the customary significance of water supplies that make life and livelihoods possible. In this case, her study explores cultural associations of groundwater flows in the karstic limestone country of Baucau including the town itself. The life-giving water that flows underground from the great origin spring of Uai Lia (water cave) feeds multiple subsidiary settlements downstream, enjoining them in complex mythical and sacrificial relationships of interdependency that have been partially obscured by state interventions to allocate flows.

For many, the liberation space of political independence offered an unprecedented opportunity for settlement return and the reclamation of ancestral entitlements and landed inheritance. Multiple households and close-knit communities have made this choice, reclaiming former settlement and garden areas in the emptied hinterlands of Timor-Leste and renewing their ties to their forebears by revisiting ancestral origin places and rebuilding sacred houses that had been neglected or destroyed. At the same time, decades of social engineering and control are not easily disentangled, particularly where customary protocols of settlement and resettlement were overridden by government authority or decree. For some communities, the desire to return is tempered by the advantages of proximity to services and the costs of starting anew. For others, the desire to remain is complicated by host-community resentments of their uninvited presence, even after many years of residence and the complications of intermarriage.

Susana Barnes discusses the social dynamics of what she calls a 'return to custom' in the south-eastern district of Viqueque. Her study reveals the complex adjustments and accommodations experienced by local Naueti communities in the process of reasserting cultural values and claims over defined ritual territories. They do so in a context marked by successive flows of in-migrants and outsiders settling on their lands and seeking livelihood spaces.

When the coercive resettlement policies of the Indonesian or the preceding Portuguese colonial regimes bypassed customary protocols and local authority structures, questions over the legitimacy of residence have frequently resulted in a variety of long-term protracted disputes. A sense of these patterns of negotiated mobility in Timor is illustrated in the contributing papers of the volume. Meitzner-Yoder's account of farming practices and relocation strategies in Oecussi highlights the creative persistence of customary arrangements, despite much reorganisation of village settlements in the enclave and the absence of any formal state recognition of local authority figures. The significance of historical mobility also features in Sandra Pannell's study, where she questions the common assumptions around seasonal farming and agrarian work as the 
principal historical livelihood strategy for Timorese rural communities. Arguing for the existence of more mobile practices of place making that allowed for adaptive adjustments to radical environmental uncertainty, Pannell considers the contribution of hunting and gathering to Timorese livelihoods, particularly in the low-population regions of eastern Timor, and argues that the diversity and flexibility of subsistence practices facilitated resistance to the Indonesian occupation. Nevertheless, the impact of Indonesian resettlement policies and political prescriptions based on idealised agrarian citizens continues to frame much government policy and planning and, according to Pannell, threatens to erase the multiple social interests and ancestral connections to forests and other non-cultivated spaces that have been emptied of their resident populations.

Ideas and claims extended to land and territory in Timor-Leste are inevitably expressions of landed authority and assertions of claim to a locally constituted legitimacy. These patterns are revealed in different ways among the contributing papers. Central to the process of asserting pre-eminence or political centrality is an appeal to continuities with ancestral foundations of settlement. The legitimacy of their claims and the political support they attract are based on narratives of ancestral itineraries and the lands on which the ancestors settled, farmed, fought over, died and were buried. It is also founded upon claims to a spiritual connection to ancestral lands, both in terms of direct sacrificial invocation to the ancestral presence and a commonly expressed cultural formulation of spiritual potency or agency, known as lulik (sacred, dangerous, taboo) and by the phrase rai na' in ('lord of the earth' in the lingua franca of Timor-Leste: Tetun), whose engagement or acquiescence confers legitimacy and landed authority to claimant groups.

Bovensiepen's study of Idaté-speaking farmers of highland Manatuto reaches similar conclusions. In their eventual return to ancestral lands following forced relocation to the regional town of Laclubar, Idate households reflect on their experience of the lulik potency of the land that was mobilised discursively as a powerful weapon of resistance and warfare, and where the authority of narrative could transform lulik potentials into ruling power (ukun). As she notes, dis-empowering situations such as those suffered by Idaté during Indonesian occupation were inverted by attributing historical agency to the spiritual potency of the land. But while the lulik properties of the land remain a source of fertility and power, the long years of absence and neglect of reciprocal obligations to the land have engendered a degree of ambivalence and anxiety.

McWilliam's contribution, drawn from Fataluku ethnography, explores a related set of cultural ideas about emplaced authority and the spirit domain. Fataluku place-making strategies and claims are seen to reflect and refract broader Austronesian cultural themes of mobility, belonging and emplaced legitimacy. As among Idaté communities, Fataluku material wellbeing and prosperity are 
held to be dependent upon the spiritual and sacrificial dimensions of social life and the living landscapes from which they and their forebears have drawn sustenance. In meeting the challenges of colonial intervention, Austronesian binary metaphors for living remain powerful symbolic principles of authority and entitlement.

Timorese populations have experienced multiple periods of social and political upheaval in living memory. What is striking to the observer is their resilience in the face of personal or collective setbacks, and their capacity to reinstate customary practices while accommodating change in a radically altered world. Hannah Arendt (1958:176-8) described this sort of adaptive response as one of natality: 'the tendency for all human action not only to conserve the past, but to initiate new possibilities.' In the ethnographic case studies of customary land attachments presented in this collection, the possibilities and limits of Timorese natality are explored. The essays confirm the view that many of the cultural principles and practices that inform customary relationships to land remain intact in contemporary Timor-Leste. For all the disruption and reconfiguring of residential arrangements that have occurred in Timor-Leste, the social institutions of customary authority continue to provide a locally legitimate basis for organising emplaced social relations and asserting seniority and authority over defined jurisdictions. The point is reinforced in Jim Fox's own closing contribution to the volume which offers a range of comparative reflections on the collected papers and the continuing vitality of Timorese cultural articulations of traditional practice.

\section{From Origin Land to Homeland: Changing cosmologies of place}

Discourses of origin as customary modalities for asserting landed authority remain a dynamic arena for asserting and contesting claims to place in contemporary Timor-Leste, but it is also apparent that the impact of Indonesian military occupation and the long struggle for independence promoted new forms of imaginative connection to land and landscape, especially around the idea of the 'homeland': Rai Timor. The idea of a national homeland draws upon assorted origin discourses, but it also reconfigures them through an imaginative, though equally politicised, construction of nation and the nationalist struggle. The powerful rallying cry of resistance, 'the warriors of Maubere' (Maubere asuwain) - once a derogatory Portuguese label for peasant farmers - came to symbolise the unity of struggle for a cultural homeland and a national identity, one that transcended the particularities of local ancestral jurisdictions and created new cosmologies of place encompassing a unity of purpose. 
But its stunning success notwithstanding, a grassroots nationalist resistance to Indonesian rule was not inevitable. Austronesian cultures, as we have noted, have rich symbolic resources for incorporating outsiders into local orders. On Timor, local political communities are traditionally represented as products of encounters between autochthonous or earlier inhabitants of the land and newcomers from the outside; the former surrender political power to the newcomers, while retaining ritual or spiritual authority, including the authority to legitimise political rulers. Versions of such diarchic arrangements are documented by Molnar, Bovensiepen, Traube, Barnes and McWilliam, who explicitly draw out their broader comparative context. With regard to the figure of the incorporated outsider or stranger king, McWilliam observes: 'The idea speaks to the historical processes of displacement in the Austronesian world of Timor whereby influential or powerful outsiders become chiefly rulers through distinctive cultural processes of incorporation.'

Despite prolonged if uneven local resistance to colonial rule, the Portuguese colonial administration overall became a beneficiary of these indigenous legitimising ideologies, even as the incorporation of ritual domains into colonial administrative systems tended to elevate local political chiefs over spiritual leaders (see Traube, Molnar, Barnes, and McWilliam, this volume). The Indonesian regime received no such dispensation. The extreme brutality of the invasion and of the protracted 'pacification' campaign that followed became seared in popular memory. The apparatus of state repression erected over the 1980s kept those memories alive, while the regime's efforts at persuasion also had the unintended effect of intensifying Timorese nationalism. The promotion of Indonesian literacy and the educational opportunities it enabled, while conducted with hegemonic intent, provided access to the world for a younger generation of East Timorese, who became central players in the resistance during the 1990s. ${ }^{10}$ Even the regime's investments in material development tended to reinforce perceptions of its destructive character. A common theme is that the Indonesian presence had antagonised the spirit guardians of nature, prompting them to ally with the resistance, like the Idaté and Fataluku land spirits (Bovensiepen, McWilliam), or to rise up on their own, like the water spirits who, according to Baucau residents, subverted an Indonesian development project through quasi-guerrilla raids and are said to have celebrated the departure of the Indonesian forces (Palmer).

Elizabeth Traube's original encounter with Aileu Mambai in 1973 was mediated by local constructions of Portuguese overseas foreigners (Malai) as returning younger brothers who rightfully assumed political rule; in her chapter, she shows how Mambai excluded Indonesians from the category of Malai and from

10 As Benedict Anderson (1998:135) observes, fluency in Indonesian did for Timorese youth what fluency in Dutch had done to the young Indonesian nationalists 70 years earlier. 
the stranger-king slot associated with it. She goes on to explore the ways in which traditional ideas of a landed spiritual authority have been reconfigured as 'the people' (povu) - a category that combines an ideology of obligation to givers of life with new notions of popular sovereignty. In Mambai conceptions, 'the people' brought the nation into being through their sacrifices: they 'purchased it' with their own lives, and the new nation-state owes them 'their livelihood' (ro ni morin) in return. Similar rhetoric of collective sacrifice and reciprocal obligation is widely used in post-independence Timor-Leste to make claims on the new nation-state. Of course, the association of shared suffering with national belonging is hardly limited to Timor-Leste and might be construed as a foreign importation. Taken together, however, the essays in this volume suggest a 'natalist' perspective on the imagery. Viewed as a new way of using the old idiom of origins to assert emplaced authority, the discourse of popular suffering appears as an Austronesian inflection of a national imaginary (Anderson 1983).

Timorese societies, as the case studies in this volume document, have traditionally maintained a strong sense of belonging to particular places. Descent groups of varying depth are referred to as 'houses' and their unity is materially embodied in named cult houses, located in settlements associated with ancestral founders. Ancestral settlements, in turn, were linked at a higher level into local political communities within which specific houses claim authority as original donors of land and of regalia of office. Models of community structure are articulated in ancestral narratives and, as the papers document, are subject to local contestation. But what needs emphasis here is the hierarchical nature of emplacement in these models. Regional origin narratives represent community formation as a top-down process wherein ancestral leaders establish asymmetrical alliances with other houses. In a recurrent motif, the ancestors order the community by distributing regalia of office that inspire sacred terror in the ruled; thus, Mambai say that flags, staffs and swords from overseas cause 'women and men to tremble and fear' (Traube, this volume), and Nauete ritual leaders claim to have delegated tasks by giving tokens to subsidiary houses 'so that those under their jurisdiction would have something to "believe in" or "fear" (Barnes, this volume).

Rai Timor is not merely a more encompassing homeland than these local communities; it is imagined in a different way, as a territory shaped from below, collectively, by the ordeals of 'the people', who become the active originators of the nation. If the constitutive act of a subject in the traditional ideology of rule is to recognise and defer to authority vested in ritual and political leaders, the constitutive act of belonging to the nation is to suffer and sacrifice for it. Such investments establish an affective tie, a more personal and intimate sense of connection than, say, the feeling of respect for an origin mountain that 
Molnar attributes to Atsabe Kemak. The mountain's represented tie, moreover, is to particular groups, whereas the nation is imagined as forged and sanctified through a struggle that mobilises the populace as a whole.

Ideas of shared struggle against the Indonesian regime thickened a sense of panethnic 'Timorese' identity cultivated under common submission to Portuguese colonial rule and became the basis for asserting a horizontal solidarity of fellow sufferers. Even before formal independence, however, a counter-tendency was also evident to distinguish unequal degrees of suffering and equate them with unequal contributions to and even membership in the nation. The rumoured claim that 'easterners' (loro sai) had 'suffered more' than 'westerners' (loro monu) territorialised an emotionally charged symbol and animated what has been described as regionalism. Publicly, at least, the claim was invoked only to be repudiated by political elites and ordinary citizens alike as a divisive distortion of historical reality. The war, people rhetorically reminded one another, had been waged and won by 'the people as a whole', not by any one part or region, and consequently, any inequality in the division of rewards was unjust. This logic was explosively evoked by the so-called 'Petitioners' - soldiers in the new Timor-Leste Defence Force (Falintil-FDTL) — whose allegations that easterners within the military were discriminating against westerners precipitated the political 'crisis' (crize) of 2006. ${ }^{11}$

If distinctions within the category of 'the people' (povu) are formally rejected, it is a widely held premise that 'the people' as a whole have suffered more for the nation than have many leaders of the new nation-state, and this perceived inequity is a source of considerable bitterness. Differential suffering has become a potent idiom of populist protest, a way of criticising the national leadership and simultaneously making claims upon the state. What is at stake is never portrayed as purely economic. Rather, perceived inequalities of wealth and opportunity are interpreted in terms of popular concepts of justice. Whether it is a matter of local claims for reparations (often asserted against neighbours) or expressing more diffuse expectations of the state, demands for material and symbolic benefits are presented as moral transactions required to compensate parties who have suffered harm. In speaking as or for 'the people', individuals rhetorically appropriate the horizontally emplaced moral authority of those whose blood flowed into the homeland and demands restitution.

In the volatile post-independence milieu, the legitimacy of the nation-state is far from assured, nor can it be secured within any of the local origin places that

11 See McWilliam and Bexley (2008:67-8). In seeming to support the allegations of the Petitioners in a speech made in March 2006, Xanana Gusmão's rhetorical point was to reiterate the idealised unity of the wartime resistance community. 
proliferate across Timor-Leste. ${ }^{12}$ Rather, its stability will depend on persuading the rural majority and unemployed youth in Dili that the nation they fought for will sustain them and help them thrive. In this respect, all look to the national government and its ability to convert the benefits of burgeoning oil and gas revenues into tangible material improvements and opportunities on the ground.

As a regional contribution to comparative Austronesian studies, the present volume offers a sustained and selective focus on just one island region of the vast Austronesian-speaking world. This is a region where the vitality of Papuan or nonAustronesian societies reveals their cultural accommodation with Austronesian cultural ideas and forms. It is also a region where the complications of military rule precluded sustained ethnographic inquiry for decades, and meant that the vibrant cultural diversity of most Timorese language communities was generally excluded from comparative scholarly consideration. The present volume seeks to redress those shortcomings and in the process highlight something of the rich specificity of Timorese ideas and practice in the light of broader understandings.

\section{References}

Anderson, B. 1983, Imagined Communities: Reflections on the origin and spread of nationalism, Verso, London.

Anderson, B. 1998, The Spectre of Comparisons: Nationalism, Southeast Asia, and the world, Verso, London and New York.

Arendt, H. 1958, The Human Condition, University of Chicago Press, Chicago.

Barraud, C. and Platenkamp, J. D. M. (eds) 1989, ‘Ritual and socio-cosmic order in eastern Indonesian societies', Bijdragen tot de Taal-, Land-en Volkenkunde, vol. 145 , no. 4 .

Bellwood, P. 1996, 'Hierarchy, founder ideology and Austronesian expansion', in James J. Fox and C. Sather (eds), Origins, Ancestry and Alliance: Explorations in Austronesian ethnography, Research School of Pacific and Asian Studies, The Australian National University, Canberra, pp. 18-40.

Budiardjo, Carmel and Liem, Soei Liong 1984, The War Against East Timor, Zed Books, London.

12 Although the charismatic appeal of Major Alfredo Reinado to westerners (especially Mambai) could be read as an index of deepening 'regional' division, it arguably owed more to a general lack of confidence in the state's commitment to justice, which Alfredo persuasively claimed to uphold. 
Commission for Reception, Truth and Reconciliation in Timor-Leste (CAVR) 2005, Chega!: The report of the Commission for Reception, Truth and Reconciliation in Timor-Leste-Executive summary, Commission for Reception, Truth and Reconciliation in Timor-Leste, Dili.

Durand, F. 2002, Catholicisme et protestantisme dans l'île de Timor: 1556-2003, Editions Arkuiris, Toulouse and Bangkok.

Durand, F. 2009, 42000 ans d'histoire de Timor-Est, Editions Arkuiris, Toulouse.

Fitzpatrick, D. 2002, Land Claims in East Timor, Asia Pacific Press, Canberra.

Fox, J. J. 1980, The Flow of Life: Essays on eastern Indonesia, Harvard University Press, Cambridge, Mass.

Fox, J. J. 1989, 'Category and complement: binary ideologies and the organisation of dualism in eastern Indonesia', in D. Maybury Lewis and L. Almagor (eds), The Attraction of Opposites: Thought and society in a dualistic mode, University of Michigan Press, Ann Arbor, pp. 33-56.

Fox, J. J. (ed.) 1993, Inside Austronesian Houses: Perspectives on domestic designs for living, The Australian National University, Canberra.

Fox, J. J. 1995, ‘Origin structures and systems of precedence in the comparative study of Austronesian societies', in P. J. K. Li, Cheng-hwa Tsang, Ying-kuei Huang, Dah-an Ho and Chiu-yu Tseng (eds), Austronesian Studies Relating to Taiwan, Symposium Series of the Institute of History and Philology: Academia Sinica 3, Taipei, pp. 27-57.

Fox, J. J. 1997, The Poetic Power of Place: Comparative perspectives on Austronesian ideas of locality, The Australian National University, Canberra.

Fox, J. J. 2000, 'Tracing the path, recounting the past', in J. J. Fox and D. B. Soares (eds), Out of the Ashes: Destruction and reconstruction of East Timor, Crawford House, Adelaide, pp. 1-29.

Fox, J. J. and Sather, C. (eds) 1996, Origins, Ancestry and Alliance: Explorations in Austronesian ethnography, Research School of Pacific and Asian Studies, The Australian National University, Canberra.

Geertz, C. 1996, 'Afterword', in Steven Feld and Keith H. Basso (eds), Senses of Place, School of American Research Press, Santa Fe, NM, pp. 259-62.

Gunn, G. C. 2001, 'The five hundred year Timorese funu', in Richard Tanter, Mark Selden and Stephen R. Shalom (eds), Bitter Flowers, Sweet Flowers: East Timor, Indonesia and the world community, Rowman \& Littlefield, Lanham, Md, pp. 3-14. 
Gunn, G. C. 2007, 'The state of East Timor studies after 1999', Journal of Contemporary Asia, vol. 37, no. 1, pp. 95-114.

Hicks, D. 1976, Tetum Ghosts and Kin: Fieldwork in an Indonesian community, Mayfield, Palo Alto, Calif.

Josselin de Jong, P. E. de (ed.) 1977, Structural Anthropology in the Netherlands, Martinus Nijhoff, The Hague.

Lameiras-Campagnolo, M. O. 1975, L'habitation des Fataluku de Lo'rehe (Timor Portugais), Thèse de doctorat de 3ème cycle, Université René Descartes, Sorbonne, Paris.

McWilliam, A. R. and Bexley, A. 2008, 'Performing politics: the 2007 parliamentary elections in Timor Leste', Asia Pacific Journal of Anthropology, vol. 9, no. 1, pp. 66-82.

Needham, R. 1978, Counterpoints, University of California Press, Berkeley.

Pélissier, R. 1996, Timor en Guerra: le crocodile et les Portugais (1847-1913), Pélissier, Paris.

Philpott, S. 2000, Rethinking Indonesia: Postcolonial Theory, Authoritarianism and Identity, Macmillan, New York.

Renard-Clamagirand, B. 1982, Marobo: une société ema de Timor, SELAF, Paris.

Reuter, T. (ed.) 2006, Sharing the Earth, Dividing the Land: Land and territory in the Austronesian world, ANU E Press, Canberra.

Robinson, G. 2001, 'People's war: militias in East Timor and Indonesia', South East Asia Research, vol. 9, no. 3, pp. 271-318.

van Wouden, F. A. E. 1968, Types of Social Structure in Eastern Indonesia, R. Needham (trans.), Koningklijk Instituut voor Taal-, land- en Volkenkunde, Translations Series Vol. 11, Martinus Nijhoff, The Hague.

Vischer, M. (ed.) 2009, Precedence: Processes of social differentiation in the Austronesian world, ANU E Press, Canberra. 